\title{
THE CLINICAL INTERPRETATION OF SOME HEMORRHAGIC STATES
}

\author{
BY
}

\author{
W. G. WYLLIE, M.D., M.R.C.P., and R. W. B. ELLIS, M.A., M.D.*
}

(From the Children's Department, Westminster Hospital, London.)

Introduction.-The differential features described in any text-book of medicine between purpura hæmorrhagica and hæmophilia would appear to make their confusion unlikely. In actual practice, however, it is often less easy to make a clear distinction. Between purpura hæmorrhagica and hereditary hæmophilia comes a varied group of cases, including sporadic and pseudo-hæmophilia and instances of hereditary and familial purpura hæmorrhagica. Moreorer, a case that at one time may have the clinical appearance of hæmophilia, may at another time present the features of purpura. It is insufficiently recognized that petechiæ in the integument are not an essential symptom of purpura hæmorrhagica, and that spontaneous bleeding from the nose, gums, and kidners, may occur in either of the conditions mentioned.

Primary purpuras have been classified as purpura simplex, purpura hæmorrhagica, purpura arthritica (Schönlein's disease), and Henoch's purpura. This subdivision has its clinical conrenience, but there is no real justification for regarding these types as distinct diseases. Some authorities have attempted to isolate purpura hæmorrhagica from the others, on account of the thrombocytopenia by which it is usually characterized. A platelet deficiency, howerer, is not a constant finding in all cases of purpura hæmorrhagica, and has been obserred occasionally in some of the other forms of primary purpura. Litten ${ }^{1}$ regarded the primary purpuras as varifties of the same disease, influenced in different cases by indiridual circumstances. Tidy $^{2}$ and Thursfield ${ }^{3}$ consider that no essential difference exists between the rarious types of primary purpura.

There are also certain cases of purpura hæmorrhagica which on blood examination are indistinguishable from the primary or idiopathic type, but which are definitely secondary to septic prccesses such as osteomrelitis and otitis media. In them a platelet deficiency is a common finding.

The object, then. of the present paper is to consider a number of cases characterized by a hæmorrhagic diathesis, and to attempt a somewhat more general survey of their relationship than is usually adopted. It will be useful as a preliminary to enumerate the usual text-book criteria of (essential) thrombocrtopenic purpura and hæmophilia. This can conreniently be done in the form of a table (Table 1 ).

* Under the tenure of a Wander Research Scholarship. 
It is apparent that none of the clinical tests enumerated can be taken by itself as a positive proof of either condition, but collectively they facilitate the differentiation of hæmophilia from purpura hæmorrhagica.

A platelet reduction is also met with in other blood diseases, such as pernicious anæmia, aplastic anæmia and lymphatic leukæmia. The number of platelets, however, in some cases of purpura hæmorrhagica may be normal. In hæmophilia the number is usually, though not invariably, normal or raised.

The producticn of petechiæ by the method of passive congestion with a tourniquet can be obtained in endocarditis lenta, and we have had a positive result with this test in a case of hæmorrhagic nephritis.

A prolonged bleeding time, thrombocytopenia, and petechiæ may be observed in lymphatic leukæmia, and petechiæ may occur in such widely different conditions as meningitis of various forms, encephalitis, typhus, and in almost any form of septicæmia.

TABLE 1.

TEXT-BOOK DIFFERESCES BETWEEX ESSENTIAL THROMBOCYTOPENIC PCRPCRA AND HEMOPHILIA.

E. T. Purpura
Hæmophilia

\author{
Present. \\ Male, transmitted by female. \\ Following direct injury. \\ Absent. \\ Negative. \\ Normal. \\ Normal. \\ Prolonged. \\ Fragile. \\ Not enlarged.
}

Spontaneous hæmorrhage from nose, kidneys, or gums, may occur in either of the conditions under discussion, and in hæmophilia ecchymotic extrarasations from blunt trauma are not uncommon. The tests of greatest value in arriving at a diagnosis are the bleeding and clotting times of the blood.

In hæmophilia a diagnosis is easy, provided a hereditary tendency is ascertainable with occurrence in the male only. It is in the sporadic cases where doubt arises. Where a history of bleeding is not obtainable in two or three preceding generations the hereditary influence cannot be excluded, for the chromosomal defect responsible for the disease can be transmitted through the females of several generations without the occurrence of bleeders among the male progeny. It is, however, certain that true sporadic hæmophilia can occur, although some examples of so-called sporadic hæmophilia, in which full pathological investigations have not been carried out, are probably cases of purpura hæmorrhagica of a type in which petechiæ are absent.

The most characteristic features of purpura hæmorrhagica are held to be the spontaneous occurrence, or artificial production by tourniquet, of petechial 
hæmorrhages; the liability to ecchymotic extravasations on minor injury ; spontaneous bleeding from mucous membranes, nose, gums, bowel and sometimes kidney ; and the prolonged bleeding time with normal clotting time in ritro. Splenic enlargement is a feature of many cases. In most instances the thrombocytes are reduced, but not necessarily in all. The critical level below which some form of bleeding is almost certain to be present is placed at 30,000 per c.mm. (the normal being 200,000 to 500,000 ), though exceptions have been recorded with a very low platelet c.ount without the occurrence of bleeding.

Two types of purpura hæmorrhagica have been described. The acute, relapsing or intermittent, and the continuous. As stated by Frank, in the first type the state of the blood in the interval between attacks may be found to be normal. The diathesis renews itself at each subsequent attack, while in the continuous type an abnormal state of the blood is constant; though clinical manifestations of the disease are not always in eridence. After considerable bleeding the blood picture frequently shows a high relative lymphocytosis, which is one of the reasons why the disease may be confused with lymphatic leukæmia. A polymorphonuclear preponderance in purpura is taken as a favourable index of marrow activity. The disease has no sex partiality, and a greater number of cases occur in the pre-pubertal period than at other ages.

Instances of hereditary and familial purpura hæmorrhagica have been recorded. Recently McKa ${ }^{-4}$ has referred to three cases of hereditary purpura hæmorrhagica in which the platelet count was normal or raised. and Witts and Conybeare ${ }^{5}$ have described the condition in two brothers. in both of whom the platelets were greatly reduced, while a sister died from epistaxis. Little and Ayres ${ }^{6}$ reported a family in which the mother and six out of nine children were bleeders. Two female children showed a greatly prolonged bleeding time with a normal clotting time. and normal or very slightly diminished platelets.

Generally speaking it may be said that blunt trauma and lesions which are sufficient to produce bleeding in the purpuric patient are ineffectual in the hæmophilic. Venepuncture and subcutaneous injections are unattended by blood extrarasation in the hæmophilic, but in cases of purpura bleeding commonly occurs at the site of needling.

As an important point of distinction between hæmophilia and purpura hæmorrhagica, Frank upholds the fact that following trauma, such as needling the lobe of the ear, there is in hæmophilia a short primary bleeding time. although after an interral there may be a prolonged after-bleeding. In purpura hæmorrhagica the primary bleeding is prolonged, but on ceasing is not repeated. Other writers hare emphasized the fact that in purpura the clot-retraction in vitro may be defectire, while in hæmophilia the clot retracts normally. but is abnormally fragile.

Methods of investigation.-The following methods of pathological investigation were employed in the cases reported below :- 


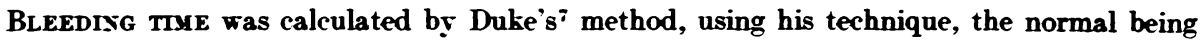
placed at 2 to $3 \frac{1}{2}$ minutes. Although this inrestigation is undoubtedly of value, it should be remembered that its employment is entirely empirical. No really satisfactory explanation has been offered as to why it is normal in the great majority of cases of hæmophilia. A prolonged bleeding time is possibly associated in some way with defective clot-retraction.

Chotrrsg TIMe (except where otherwise stated) was estimated on capillary blood by the capillary tube method. Two lengths of standard capillary tube were filled with blood obtained by needle prick from the lobe of the ear, and were kept at $37^{\circ} \mathrm{C}$. After two minutes the first tube was broken at intervals of 30 seconds until a continuous thread of clot was obtained between the two broken fragments. The second tube was then broken in the same way until clotting occurred, which was usually 15 to 30 seconds later than in the first tube owing to the less frequent manipulation of the second. The total time from the filling of the second tube to the occurrence of clot formation in it was taken as the clotting time (normal 2 to 4 minutes).

Puateicts were counted per 1,000 red blood corpuscles in the Thoma Zeiss counting chamber, the blood being obtained from the finger by a needle prick made through a drop of 2 per cent. citrate solution. The drop of blood and citrate solution was transferred to a wax chamber by means of a freshly waxed pipette and further diluted with citrate solution. The counting chamber was filled with the fluid and allowed to stand for half an hour to allow the platelets to settle. The platelets per 1,000 R.B.C. were then counted. A red blood cell count was carried out in the usual way, and the platelets per c.mm. calculated. The majority of platelet counts were carried out in duplicate and the average value taken. Counts between 200,000 and 500,000 per c.mm. were considered as within normal limits.

SERCY Calcity was estimated by the method of Kramer and Tisdalls.

\section{Clinical reports and commentaries.}

The following ten cases of abnormal bleeding in children illustrate certain inter-relationships both in their symptoms and in their pathological findings. By the criteria already described, the first four would be generally recognized as hæmophilia ; Case 6 as Henoch's purpura ; and Cases 7 and 8 as thrombocytopenic purpura. Case 5 has certain features in common with both hæmophilia and purpura, which render its classificetion problematical, while in the last two cases the diagnoses made were lymphatic leukæmia with osteomyelitis and Banti's disease respectively. Attention is partizularly drawn to those features which may exist in common between the hæmorrhagic states, and render hard-and-fast distincticns difficult.

Case 1.-F.M., male, aged 5 years. One sibling, female, aged one year and three months, healthy. No family history of hæmophilia in the three preceding generations. Patient was first admitted to hospital November 16th, 1928, aged 2 years and 8 months, suffering from impetigo and carious teeth. The extraction of 8 teeth was followed by prolonged hæmorrhage, gradually ceasing after 9 days. A blood transfusion was given on the fourth day of bleeding.

On re-admission, 3.1.30, a right lower molar with pus at its root was extracted and the socket plugged. Hæmorrhage occurred intermittently, becoming more serere on the fourteenth day, and requiring blood transfusion.

Re-admission 20.2.31, with six days' bleeding from a bitten tongue. The bleeding ceased after three days.

Pat hologizal fisdrsgs. 12.12.28. Clotting time, 6 minutes; platelets, 300,000 per c.mm.

4.11.29. Clotting time, 6 minutes; platelets, 100,000 per c.mm.; R.B.C., 5,400 000; Hb., 66 per cent.; C.I., 0.55 ; W.B.C., 10,000 ; Polym.neutrophils, 45 per cent. ; eosinophils, 4 per cent. ; mononuclears, 6 per cent. ; lymphocytes, 45 per cent.

8.1.30. Clotting time, 10 minutes.

20.1.30 (after considerable hæmorrhage). R.B.C., 2,800,000; Hb., 47 per cent.; C.I., 0.72 ; platelets, 560,000 per c.mm. 
24.2.31. Bleeding time. 6 minutes; clotting time. 7 minutes; R.B.C.. 3.600.000 : Hb., 47 per cent.; C'.I.. 0.65; W.B.C.., 7,800.

26.2.31. Platelets, 325.800 per c.mm.

16.3.31. Bleeding time, $4 \frac{1}{2}$ minutes ; clotting time, 4 minutes.

Case 2.-J.J., male, aged $4 \frac{1}{2}$ years. There is one other child, a boy, aged 2 years, who has shown no tendency to bleed. and there is no history of bleeders in the mother's family, traced back through fire generations.

The patient had oozing of blood from the narel 17 dars after birth. which continued for 10 days. Since then he has had many hæmorrhages, epistaxis, prolonged bleeding after biting his lip. and from a pinprick of the lobe of the ear, and a hæmorrhage into the left knee joint. He also bruises rery easily from blunt trauma, but has nerer shown spontaneous petechiæ, nor splenic enlargement.

Pathological fivisigs. 4.12.30 (no hæmorrhage at this date). R.B.(., 3,768,000; W.B.C.. 10,800 ; Polỵmorphonuclears, 33 per cent. ; lỵmpho?vtes., 67 per cent. ; platelets, 120.570 per c.mm.

19.2.31. Bleeding time, 4 minutes 15 seconds; clotting time, 10 minutes 30 seconds.

Commert.-Both the abore cases show the clinical picture of hæmophilia, but in neither is there any traceable family history of abnormal bleeding. Case $\dot{z}$ especially, where the family history on the mother's side was traced back for fire generations, indicates 'sporadis' bleeding. In both the clotting time is definitely, though not greatly, prolonged and the bleeding time slightly so. Diminished platelets were found in each case on one occasion, though in the first, where repeated estimations were carried out, subsequent platelet values were normal. The rariation in clotting time seen in Case 1 is a not infrequent finding in hæmophilia.

Case 3.-W.B., male, aged $6 \frac{1}{4}$ rears. The patient's mother was one of eight children (5 bors, 3 girls); her two eldest brothers were bleeders. The patient has two younger brothers. both bleeders. The history of the rounger is giren in detail below. The middle brother required blood transfusion recently for prolonged bleeding following extraction of teeth. Two older brothers and one sister hare shown no abnormal bleeding.

Patient has had repexted blood transfusions for hæmorrhages following slight traumat 3 since one year of age. Hæmaturia of short duration occurred September, 1930. and a large hæmatoma of the left leg followed the bite of an insect in the ensuing month. He was admitted to hospital on May 18th, 1931, with the left elbow swollen and discoloured. but with no history of trauma. Recovery was unerentful.

Pathological fisdrsgs. 18.5.31. Clotting time, 9 minutes 12: seconds : bleeding time. orer 10 minutes; clot retraction normal. R.B.C., 3,440,000; platelets, 509,1 20 per c.mm.: serum calcium, 9·4 mgrm. per cent.

Case 4.-A.B., brother of Case 3. aged 3 years 4 months. Patient bled from the narel for three days at birth. Since then he has had repeated oozings of blood following minor injuries. but has not required transfusion. He has twice been admitted to hospital, once for persistent bleeding lasting ten days from an abrasion of the lower lip. and once for extensire hæmatoma of scrotum and of lower abdomen following trauma.

Pathological fivdisgs. 30.12.30. R.B.C., 3,030,000 : Hb., 44 per cent. : C.I.. 0.7: W.B.C., 7,000 ; Polym.neutrophils, 59 per cent.; lymphocytes, 41 per cent. ; platelets, 380.000 per c.mm. Bleeding time. $3 \frac{1}{2}$ minutes ; clotting time. 9 minutes; serum calcium, 8.5 ngrn. per cent.

31.12.30. Prothrombin time (renous blood. Howell's method ${ }^{3}$ ). 76 minutes (approximately 5 times normal control).

Commert. - In contrast to the first two cases. Cases 3 and 4 adhere much more closely to the classical picture of hæmophilia. Not only are the family and clinical histories typical, but the blood findings include normal 
platelets and definitely prolonged clotting time in koth cases. Thus, while there is no question as to the diagnosis of hæmophilia, it is of considerable interest that the bleeding time in Case 3 is over 10 minutes, a finding completely at variance with the normal bleeding time usually described.

Case 5.-J.T., male, aged 10 years, with no family history of hæmophilia or purpura. The patient has bled freely from trivial injuries since infancy. At eight years of age a large swelling appeared on the right thigh, following trauma, and since then he has had several swellings of the shoulder and knee joints. In January, 1931, there was swelling of the right knee, extensive bruising of the upper chest, oozing from the gums, and a blood-stained discharge from the ears.

On admission to the Westminster Hospital the right knee showed fixed flexion at $90^{\circ}$, and the presence of a considerable effusion which was fluctuant in its upper and outer margins and pitted on pressure. There was no redness or tenderness. Glands were palpable in the neck and groins, and the spleen was enlarged one finger's breadth below the costal margin. The tonsils were enlarged and a bilateral aural discharge was present. The patient had a low grade temperature for three to four weeks in hospital, but subsequently became apyrexial. Spontaneous bleedings from the gums occurred repeatedly; on one occasion sufficiently severe to necessitate transfusion. There was also prolonged bleeding from a small head injury. The spleen remained slightly enlarged, but no further glandular enlargement occurred. The patient was discharged to convalescence after four months.

Pathological findings. On admission: Bleeding time, 13 minutes; clotting time, 45 minutes.

30.4.31. Bleeding time, $6 \frac{1}{2}$ minutes; clotting time, 21 minutes (venous). Blood calcium, 11.5 mgrm. per cent.

15.5.31. R.B.C., 4,230,000 ; Hb., 71 per cent. ; C.I., 0.84 ; Polym.neutrophils, 72 per cent. ; mononuclears, 2 per cent.; lymphocytes, 26 per cent.; platelets, 60,000 .

21.5.31. Bleeding time, $5 \frac{1}{2}$ minutes ; clotting time (capillary), $6 \frac{1}{2}$ minutes.

18.6.31 (after prolonged hæmorrhage from gums). R.B.C., 2,180,000; Hb., 35 per cent. ; C.I., 0.83. Patient was transfused; blood Group II.

29.6.31. R.B.C., 2,500,000; Hb., 43 per cent.; C.I., 0.86.

Comment.-It has already been emphasized that certain cases exist which show features in common with both hæmophilia and purpura, and provide as it were a half-way house between the two conditions. The above case is a good example. He was admitted to hospital with what was regarded as a hæmophilic joint, and in view of the very greatly prolonged clotting time (45 minutes) and the negative tourniquet test, he was shown at the Children's Section of the Royal Society of Medicine (April, 1931,) with that tentative diagnosis. In favour of purpura, however, were the considerably prolonged bleeding time, the reduction of platelets and the enlarged spleen. The clotting time was subsequently reduced to $6 \frac{1}{2}$ minutes and repeated spontaneous hæmorrhages from the gums became the chief clinical feature of the case. It is probable that if he had been seen for the first time at this stage a diagnosis of purpura would have been made. The picture was somewhat complicated by the presence of a septic focus and a low grade temperature on admission, and it is possible that the reduction of platelets may have been associated with this. No petechial lesions, however, occurred at any time and the tourniquet test was consistently negative.

Case 6.-D.R., male, aged 5 years and 4 months, was admitted to hospital on July 15th, 1930, with a history of sore throat and vomiting for 3 days, occurring 3 weeks before admission. The day before admission the child complained of severe pains in the right knee, followed by pains in the left leg and both arms. The temperature was $101^{\circ}$. On examination he appeared well- 
nourished and of good colour. Fine purpuric spots were scattered orer the buttocks and perineum and in a patch behind the right knee. The right knee and shoulder were painful on passive morement. Two days later the abdomen became distended and diffusely tender, especially in the left hypochondrium. The spleen was not palpable. There were also swelling and tenderness orer the lumbar spines. Radiographs of the right knee and lumbar spines were negative. In the course of the following two days the abdominal pain increased and there was eridence of free peritoneal fluid. Hæmorrhage from the bowel occurred on three consecutive days. The general condition then rapidly improved and the child was discharged home with no physical signs of disease. When seen nine months later he had had no recurrence of purpura, or of hæmorrhage from the bowel. No history suggestive of allergy was obtained.

Pathological fisdisgs. 16.7.30. R.B.C., 5,840,000; Hb., 77 per cent.; C.I., 0.60; W.B.C., 10,200 ; Polym.neutrophils, 76 per cent.; eosinophils, 3 per cent.; mononuclears, 1 per cent.; lirmphocrtes, 20 per cent. ; platelets, 650,000 .

20.4.31. R.B.C., 4,400.000 ; Hb., 81 per cent.; C.I., 0.92 ; W.B.C., 6,200 ; Polym.neutrophils, 42 per cent. ; ecsinophils, 3 per cent. ; mononuclears, 1 per cent.; lymphocytes, 52 per cent. ; transitionals, 2 per cent. ; platelets, 600,000 . Bleeding time, 1 minute 50 seconds ; clotting time, 3 minutes.

Commest.-This case shows the characteristic picture of Henoch's purpura, a condition which has been considered by many writers to be due to an allergic diathesis. It will be noted that the occurrence of spontaneous bleeding from the bowel and of purpuric skin lesions was here unassociated with any reduction in platelets, whose number was, in fact, abnormally high. As may occur in all varieties of purpura the onset was accompanied by serere arthritic pains and was preceded by an upper respiratory infection.

Case 7.-I.M., female, aged 6 years. Patient was admitted with a history of repeated and severe epistaxis for two weeks. There was no previous history of bleeding and her general health had been good. A brother, aged 7 years, was healthy. On admission the patient showed scattered purpuric lesions on the back, abdomen and legs, with oozing of blood from nose and gums, and extensire ecchrmoses on the limbs. The heart was dilated and a srstolic murmur was heard at the base. There was no eridence of local sepsis. The occurrence of repeated epistaxis necessitated blood transfusion (300 c.cm.) nine dars after admission, and again two days later. The spleen was removed by Mr. Tudor Edwards after the second transfusion. The organ weighed $60 \mathrm{grm}$. and showed some perisplenitis. The patient was transfused on the erening of the day of operation and again ten days later. The operation did not appear to have any immediate effect on the bleeding, and a fifth transfusion was given before her discharge from hospital. She was re-admitted six weeks later for recurrent epistaxis since discharge and was given intramuscular injections of normal horse serum in an attempt to produce a protein shock. The last injection was followed in 24 hours by transient joint pains and a rery extensive fine purpuric rash. When seen in May, 1931, eight months after splenectomy, the patient still showed an extensire purpuric eruption and ecchrmoses on the limbs, with a recent history of two serere attacks of epistaxis.

Pathological findesgs. On admission: R.B.C., 2,143,000 ; Hb., 45 per cent.; C.I., 1.00 ; W.B.C., 7,200 ; Polym.neutrophils. 62 per cent. ; mononuclears, 6 per cent. ; lymphocrtes, 32 per cent.; platelets, 125,000 per c.mm. The patient bled profusely when pricked for blood count. The platelet count fell to 6.000 a month after splenectomr, with a subsequent rise to 45,000 two months later. Clotting time was normal throughout.

Bleeding time :-

1 month after operation, 18 minutes.

$\begin{array}{lcccc}6 \text { weeks } & , & , & 7 \frac{1}{2} & , \\ 3 \text { months } & , & , & 23 & , \\ 8 \text { months } & , & ., & 18 & \text {., }\end{array}$

Yay, 1931 (8 months after splenectomy). R.B.C., 4,110,000; W.B.C., 13.000 ; Polym. neutrophils, 51 per cent.; eosinophils. 1 per cent.; transitionals, 1 per cent.; mononuclears, 2 per cent. ; lymphocytes, 45 per cent. ; platelets, 12,000 . 
Report by Dr. Braxton Hicks on spleen: There is a general increase in connective tissue, and the splenic pulp appears as an open sponge, particularly at the periphery. The lymphocytes have for the most part disappeared, with the exception of the Malpighian corpuscles.

Commext.-The case shows the features of a typical thrombocytopenic purpura, prolonged bleeding time, reduced platelets, normal clotting time, and clinically the occurrence of spontaneous purpuric lesions and free hæmorrhages. There was no family history of bleeding nor evidence that the condition was of secondary origin. Neither the clinical nor pathological condition was appreciably benefited by splenectomy, and the marked rise in platelets which frequently follows this operation did $n$ st oscur.

Case 8. - V.L., female, aged 7 rears, 4 months. There was no family history of abnormal bleeding. Since the age of 3 years the patient has suffered from epistaxis, excessive bruising, and purpuric lesions. A serere hæmorrhage followed the extraction of three teeth in June, 1929, cn account of which she wes admitted to hospital for one week. At this tirce it was noted that the tonsils and tonsillar glands were both enlarged, and that purpuric lesions were present. Occasional epistaxis occurred during the succeeding fifteen months.

In Norember, 1930, the left ear began to discharge and blood appeared in the urine, both hæmaturia and aural discharge continuing until after tonsillectomy was performed in January, 1931. Blood transfusions were given before and after operation. which was accompanied by considerable hæmorrhage. Pus from a submental abscess, which dereloped one week later, grew streptococci in pure culture. The urine cleared in March, 1931. A cortical mastoid operation was next performed on March 16th by Mr. Chubb. The mastoid cortex and cells were found filled with pus and polypoid granulation tissue : the dura was exposed and showed early involvement. The following day the urine again contained blood in large amount, the hæmaturia persisting for several weeks.

Pathological findisgs.

22. 7.29. Platelets, 203,000 .

24. 9.29. $\quad 100,000$.

7.11.30. $\quad 49,000$. Bleeding time, 6 minutes; clotting time, $5 \frac{1}{2}$ minutes.

6. 1.31. ., $\quad 56,000$.

11. 2.31. , 30,000 .

16. 2.31. , none seen.

9. 3.31. ., $\quad \mathbf{5}, 000$.

14. 3.31. $, \quad 2,000$.

R.B.C., 4,600,000; Hb., 81 per cent.

R. B.C., $3, \ddot{570,000 ; ~ H b ., ~} \tilde{5} 8$ per cent..

, $2,710,000 ; \quad, 49 \quad$,

, 4,500,000; ,, $71 \quad$,

.. 4.020,000; ," $68 \quad$,,

Coxmext.-The above case illustrates the close association which may exist between purpura hæmorrhagica and sepsis. While we cannot here definitely attribute the earliest symptoms to an infective cause, it was, however, noted that septic tonsils were present when the child first came under obserration, and the simultaneous occurrence of aural discharge and hæmaturia in November, 1930, was striking. Similarly, after the hæmaturia had ceased, an exacerbation of the renal bleeding immediately cccurred when an infected mastoid was opened up.

It is possible that certain cases of co-called ' hæmorrhagic' or glomerular nephritis, in which the close association with tonsillar or other infection is well recognized, should be considered as falling into the same group as purpuric hæmaturia. The production of petechiæ by the tourniquet in one such case has already been mentioned.

The role of hæmolytic streptococci in the causation of purpura has recently been discussed by Langmead ${ }^{10}$. In this case a streptococcus was obtained from pus from a submental abscess. 
Case 9.-J.S.. female, aged 4 years. no relerant family history. The previous health was good with the exception of swollen cervical glands one year before admission.

Patient was admitted to hospital on July 30th. 19:29, with sereral weeks history of pallor and loss of appetite. For $\mathbf{5}$ days she had been drowsy and suffered from severe diarrhœa which had become bloody. For two days petechial lesions had appeared on the buttocks and limbs, and extensive bruising had occurred on both legs. On examination, the patient showed marked pallor of the mucous membranes, with bilateral enlargement of the cerrical glands, and a few shotty glands were in the axillæ and groins. The throat appeared healthy, the liver was enlarged two fingers' breadths below the costal margin, but the spleen was not palpable. A soft systolic murmur was heard at the apex of the heart. Scattered petechiæ were present on the abdomen, buttocks and limbs, and extensire ecchrmoses on both legs. The temperature was $102^{\circ}$.

In view of the serere degree of anæmia the patient was giren a blood transfusion on August 3rd, which was followed by some improrement in her general condition. Six days later she developed a fluctuant swelling over her right tibia. which when opened and evacuated appeared to be an infected hæmatoma. She continued to run an irregular temperature. Radiographs (17.8.29) showed periostitis of the right tibia with presence of a small sequestrum. Subsequently recurrent crops of petechial lesions occurred on the buttocks. and two abscesses in the buttocks required to be opened and drained. Staphylococcus aureus was obtained on culture. On discharge there was some improvement in the general condition. but one month later serere anæmia and glandular enlargement were erident. The patient died some weeks later while at home, but a post-mortem examination was not obtained.

TABLE 2.

Pathological fisdisgs is Case 9.

\begin{tabular}{|c|c|c|c|c|c|c|c|c|c|}
\hline Date & R.B.C: & $\mathrm{Hb}$. & C.I. & W.B.C. & Pmn. ${ }^{\circ}{ }_{0}$ & Eosin. ${ }^{\circ}$ & Mon. ${ }^{\circ}$ & Lymph. ${ }^{0}$ & Platelets \\
\hline 31.7 .29 & $2,300,000$ & 28 & $0 \cdot \pi$ & 2.300 & 14 & 0 & 11 & 75 & - \\
\hline 19.8 .29 & $4,230,000$ & 64 & $0 \cdot 76$ & 9,400 & 57 & 0 & 0 & 43 & 100,000 \\
\hline 28.8 .29 & - & 81 & - & - & 59 & 1 & 8 & 32 & - \\
\hline 16.9 .29 & $4,000,000$ & 70 & 0.87 & 8.800 & 30 & 4 & 6 & 60 & - \\
\hline 26.9 .29 & $4,420,000$ & 78 & $0 \cdot 88$ & 7,800 & 3 & 1 & 1 & 95 & - \\
\hline
\end{tabular}

*Clotting time, $4 \frac{1}{2}$ minutes. Prolonged bleeding took place from needle wound made for blood counts. Agglutination against B. typhosus, B. paratyphosus A. and B., negative.

CoMment.-From the blood count a provisional diagnosis of lymphatic leukæmia was made in this case. It will be seen that although considerable temporary improvement occurred in the blood picture following transfusion, the last differential count showed 95 per cent. of the white cells were of the lymphccytic series. The picture was complicated by the occurrence of osteomyelitis of the right tibia. Associated with these conditions, the patient showed the typical features of purpura hæmorrhagica, purpuric lesions of the skin, spontaneous bleeding from mucous membranes, thrombocytopenia, prolonged bleeding time and a normal clotting time.

Case 10.-R.B., female, aged 6 years. Six months before admission the patient had an attack of jaundice and malaise lasting for fire weeks following infection of left maxillary antrum. Next, she had spontaneous bleeding from the gums, dark urine and black stools on several occasions, and recurrent crops of 'dark spots ' (? telangiectases) on the skin which faded gradually with change of colour. The previous health had been good. There was no family history of either jaundice or abnormal bleeding.

On admission the patient showed extensire telangiectases on the face and a few similar esions on the left forearm and right hand. Both liver and spleen were enlarged two fingers 
breadths below the costal margin and were firm and non-tender. The patient was giren a transfusion of whole blood and the spleen remored the following day. At operation the liver was found to be in a condition of early cirrhosis. On discharge from hospital the patient was free from symptoms.

Pathological fisdisgs. 16.4 .30 (before operation). R.B.C.. 4.120 .000 ; Hb., 80 per cent.: C.I., 0.97; W.B.C., 7,200 : Polym.neutrophils, 39 per cent.; mononuclears, 10 per cent. ; lymphocytes, 51 per cent. Fragility : hæmolysis began in 0.5 per cent. saline (control 0.45 per cent.), and was complete in 0.4 per cent. saline (control 0.35 per cent.).

24.4.30 (before operation), platelets, 71,000 per c.mm.

5.5.30 (9 dass after operation), R.B.C., 2.760,000 : W.B.C., 43.800 : Polym.neutrophils, 89 per cent.; mononuclears, 0 ; lymphocytes, 9 per cent.; basophils. 2 per cent. ; platelets, $\mathbf{2 5 0 , 0 0 0}$ per c.mm.

21.5.30. R.B.C., $6,130,000$; platelets, 210,000 per c.mm.

3.9.30. R.B.C., 4,800,000 ; Hb.. 86 per cent. ; C.I., 0.9 ; W.B.C., 6,500 ; Polym.neutrophils, 43 per cent. ; eosinophils. 1 per cent.; lụmphocytes, 52 per cent. ; mononuclears, 2 per cent.

Report by Dr. Braxton Hicks on spleen (removed at hospital) : Weight $7 \frac{1}{2}$ oz. The spleen exhibits the changes usually seen in splenomegaly with anæmia, only to a slighter degree. There is general increase in the fibrous tissue. Not only is the capsule thickened, but the trabeculæ and Malpighian corpuscles and pulp show excess of fibrous tissue. The characteristic fibrous sponge tissue of the pulp, with disappearance of the pulp cells, is well seen particularly at the edge of the spleen.

CoMmest.-The above case is clearly one of Banti's disease in which both spleen and liver showed evidence of early fibrosis. It will be seen that the clinical history includes the presence of skin lesions, though of a different type from those seen in purpura. Spontaneous bleeding occurred from the gums, and the platelets were considerably reduced when first estimated but rose after splenectomy. Thus the case shows certain points of similarity to purpura hæmorrbagica, although the underlying ætiology is probably quite different. The occurrence of telangiectases suggests a possible relationship with a group of cases described by Parkes Weber ${ }^{11}$, in which familial or nonfamilial telangiectases of congenital-derelopmental nature were associated with a hæmorrhagic tendency.

\section{Discussion.}

In arriving at a satisfactory conception of the causes of abnormal bleeding, the three factors that may be involved must be considered. These are the platelets, the permeability of the capillary endothelium, and the blood plasma. Thus in the case of hæmorrhagis purpura where the process of bleeding involres a diapedesis of red blood cells through unbroken capillary walls, the blood platelets, which in the majority of cases are much reduced, and the capillary endothelium hare been rariously held responsible. In typical hæmophilia, on the other hand, where bleeding does not occur with intact capillaries and where the platelets are normal or slightly raised in number, the blood plasma is generally regarded as being the defectire element.

The number of classifications of purpura adranced is in itself an index of how little is known of its essential causation. Denys ${ }^{12}$ and later Frank ${ }^{13}$ both considered that reduction in the number of platelets should be regarded as the factor responsible for hæmorrhage. Tidy ${ }^{2}$ on the other hand insists that no clinical grouping corresponds with the reduction of platelets, and that several of Frank's original 'thrombopenic' cases would have to be classified 
clinically as purpura simplex, i.e., showing petechial hæmorrhages but no free bleeding, whilst free bleeding may occur in purpura without the platelets being diminished. Tidy regards the reduction of platelets in the general circulation as secondary to their becoming adherent to damaged capillary walls in an attempt to prevent diapedesis. The experimental work of Bedson ${ }^{14}$ is of interest in this connection since it suggests that neither reduction of platelets nor damage to capillary endothelium can alone produce purpura in rabbits, but when both factors are combined purpuric lesions result. Similarly with regard to the role of the spleen considerable dirergence of opinion exists, Kaznelson ${ }^{15}$ and others holding that destruction of platelets occurs in this organ, while Frank ${ }^{16}$ supports the riew that the thrombocytopenia is due essentially to diminished production by the bone marrow, which would suggest that the spleen excretes a myelotoxin. It is certain, however, that in many cases splenectomy results in a rapid rise in platelets, though these maysubsequently fall again to normal or subnormal levels.

It is clear that sepsis may be intimately connected with the production of hæmorrhagic purpura, this being well illustrated by Case 8 and by two cases recently published by Coke $^{1 i}$. In all of these the platelets were greatly reduced. The interpretation put on these findings will depend on the riew of platelet action adopted. Sepsis may either act in these cases by direct suppression of platelet formation by the bone marrow, or may have a damaging effect on the capillary endothelium. The case of hæmorrhagic nephritis already referred to in which the tourniquet test produced an extensive crop of purpuric lesions, but in which the platelets were not reduced, suggests that the latter may be the case.

Neither the platelets nor the capillary endothelium appear to be defective in hæmophilia, and the fact that unwashed platelets in this condition were found more resistant to lysis than those of normal blood is probably explained by their being surrounded by a film of relatively stable plasma (Pickering18). It is this abnormal stability of the plasma that is the characteristic feature of the disease. All the known elements of the plasma appear to be normally present, and though rare cases of greatly delayed clotting in vitro due to lack of fibrin (Opitz and Magda ${ }^{19}$, Rabe and Salomon ${ }^{20}$ ) and deficient calcium (Hess ${ }^{21}$ ) hare been described, they have little in common with true hæmophilia. Addis $^{22}$ concluded that the abnormal stability of hæmophilic plasma was due to a prolongation of the time of change of prothrombin into thrombin, and Pickering and Gladstone ${ }^{23}$ suggest that this represents 'a persistence or reappearance in adult life of an embryonic condition of the plasma.'

From the pathological standpoint it would appear, therefore, that in purpura we have a 'platelet-capillary' complex responsible for hæmorrhage, while in hæmophilia the plasma is abnormal. Both these factors may be inherited or both may arise de novo. The mode of transmission differs in the two cases, howerer, since the hæmophilic factor is sex-linked while the purpuric diathesis affects males and females equally. It is of interest to find, therefore, that purpura hæmorrhagica occurs not infrequently in the females of hæmophilic families (Hess ${ }^{24}$ ). Bauer and Wehefitz ${ }^{25}$ have described thrombocytopenia in such cases. 
Although it is difficult to explain satisfactorily on a pathological basis a relationship between hæmophilia and purpura, it should be clearly recognized that such exists. The evidence for their relationship is :-

1. The occurrence of abnormal bleeding of purpuric type in the females of some hæmophilic families with, in certain cases, the full picture of thrombocytopenje purpura.

2. The occurrence of isolated features characteristic of purpura in certain cases of hæmophilia, and rice rersa.

3. Occasionally alternation of the hæmophilic and purpuric state may occur in the same individual. An excellent example of this is furnished by a case described by Pickering ${ }^{18}$, and our fifth case (J.T.) illustrates the same point to some extent.

Similarly, the same clinical and pathological picture may be present in primary purpura arising sporadically or familial in crigin, and in purpura which is secondary to sepsis, toxins, or other pathological conditions. In both primary and secondary types the platelet-capillary complex is affected.

In considering cases of abnormal bleeding, therefore, it is well to remember that although the great majority can be conveniently classified, a number of atypical cases will remain to remind us that much of our classification is arbitrary and that no absolute division exists between certain disease entities.

We wish to express our sincere thanks to Dr. Donald Paterson and to Mr. Rock Carling for permission to report cases under their care, and to Dr. Braxton Hicks for his help and supervision of the pathological examinations.

\section{REFERENCES.}

1. Litten. M., Speciele Pathol. u. Therap. (Nothnagel). 1898. VIII. part 3, 343.

2. Tidy, H. L., Lancet, Lond., 1926, ii, 365.

3. Thursfield, J. H., Diseases of Children, Garrod, Batten, Thursfield, and Paterson. Lond., $1929,4 \pi$.

4. McKay, W., Quart. J. Med., Oxf., 1931, XXIV, 285.

5. Witts, L. J. \& Conybeare. E. T., Proc. Roy. Soc. Med.. Lond., 1931, XXIY. 709.

6. Little, W. D., \& Arres, W. W., J. Am. Med. Ass., Chicago, 1928, XCI, 1251.

7. Duke, W. W., Ibid., 1910, LY, 1185.

8. Kramer, B. \& Tisdall. F. F.. J. Biol. Chem.. Baltimore, 1921. XLVII, 475.

9. Howell, W. H., quoted by Todd, J. C., Clinical Diagnasis by Laboratory Methods, Lond., 1924, $2 \mathbf{4 9}$.

10. Langmead, F., Arch. Dis. Childh.. Lond.. 1931. VI, 205.5.

11. Weber, F. P., Brit. J. Child. Dis., Lond.. 1924. XXI, 198.

12. Denrs, J., La Cellule, Lourain, 1887. III. 445.

13. Frank, E.. Berlin klin. Woch.. Berlin. 1915. LII, 454, 490. 961.

14. Bedson, P. H., J. Path. and Bact., Edin., 1922, XXV. 94. Ibid., 1924, XXVI, 176.

15. Kaznelson, P., Zt. f. klin. Med., Berlin, 1919. LXXXVII. 133.

16. Frank, E., Schittenhelm's Krankheiten des Blutes, Berlin, 1925, II, 289.

17. Coke, H., Brit. Med. J., Lond., 1931, i, 535.

18. Pickering, J. W., The Blood Plasma. Lond., 19-28. 200 and 203.

19. Opitz, H. \& Magda, F., Jahr. f. Kinderheil.. Berlin. 1921, XCIV, 374.

20. Rabe, F. \& Salomon. E., Deut. Arch. f. klin. Med.. Leipzig, 1920. CXXXII, 240.

21. Hess, A. F., Bull. Johns Hopkins Hosp. Baltimore. 1915. XXVI. 372.

22. Addis, T., J. Path. and Bact., Edin.. 1911. XV. 427.

23. Pickering. J. W. \& Gladstone. R. J., Lancet. Lond., 1925. i. 60:2.

24. Hess, A. F., Arch. Int. Med., Chicago, 1916. XVII. 203.

25. Bauer, K. H. \& Wehefitz, E., Archit. f. Gynakol., Berlin, 1924, CXXI, 462. Ibil., 1926, CXXIX, 1. 